Discussion Papers

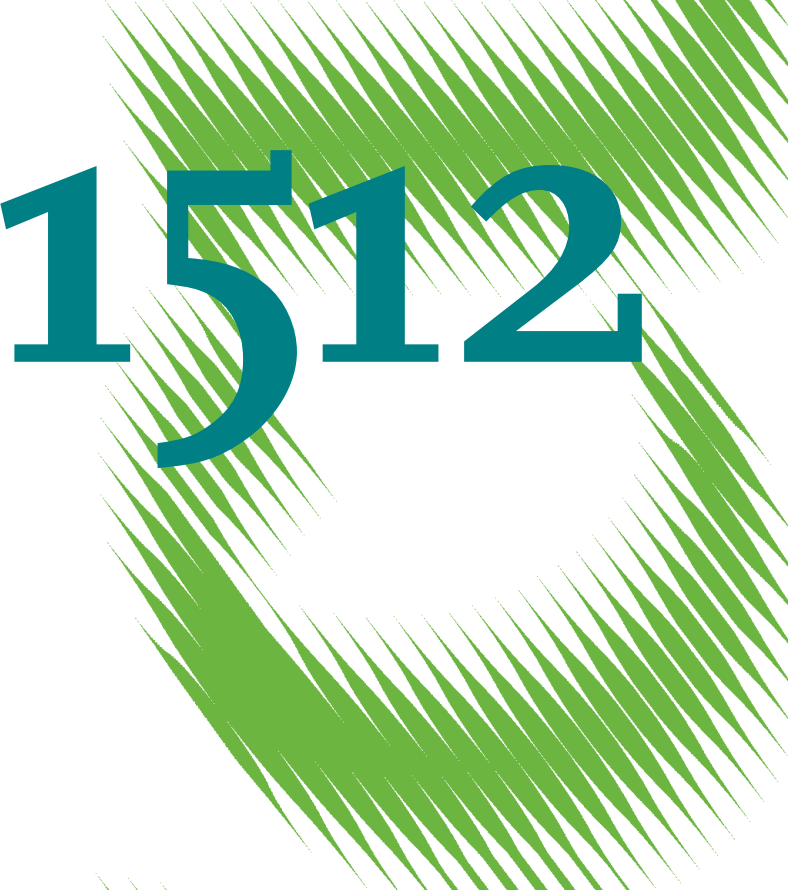

Regulation and Investment Incentives in Electricity Distribution An Empirical Assessment 
Opinions expressed in this paper are those of the author(s) and do not necessarily reflect views of the institute.

IMPRESSUM

(C) DIW Berlin, 2015

DIW Berlin

German Institute for Economic Research

Mohrenstr. 58

10117 Berlin

Tel. +49 (30) $89789-0$

Fax +49 (30) $89789-200$

http://www.diw.de

ISSN electronic edition 1619-4535

Papers can be downloaded free of charge from the DIW Berlin website:

http://www.diw.de/discussionpapers

Discussion Papers of DIW Berlin are indexed in RePEc and SSRN:

http://ideas.repec.org/s/diw/diwwpp.html

http://www.ssrn.com/link/DIW-Berlin-German-Inst-Econ-Res.html 


\title{
Regulation and Investment Incentives in Electricity Distribution: An Empirical Assessment
}

\author{
Astrid Cullmann* Maria Nieswand
}

October 2015

\begin{abstract}
We analyze the effects of an incentive based regulatory scheme with revenue caps on the investment behaviors and decisions of 109 electricity distribution companies operating in Germany in 2006-2012. We hypothesize that Germany's implementation of incentive regulation in 2009 has a negative impact on total investment, and that firms increase their investments in the base year. We build a model that controls for both firm-specific heterogeneity and ownership structure and test it with the German data. The results show that investments increase after incentive regulation, and that the institutional constraints used to determine the revenue caps influence the distribution companies' investment decisions. We also note that the investments increase in the base year when the rate base is determined for the following regulatory period. We conclude that a comprehensive assessment of Germany's electricity distribution companies' investment decisions and behaviors should account for firm specific heterogeneity. It should further include all institutional aspects of incentive regulation to design incentives that will foster investments in the region's energy networks.
\end{abstract}

JEL-Classification: L94, L51, L98

Keywords: Incentive Regulation, Electricity Distribution, Investments, Germany

\section{Introduction}

Electricity distribution across Europe varies in the size of operational areas, the number of customers, network characteristics, and ownership structures. Increasingly, European regulators and distribution system operators (hereafter DSOs) will need to address the expected very large investments in infrastructure expansion and modernization required to achieve carbon-free generation. For instance, European transmission and distribution networks together will require 600 billion Euros of investment by $2020^{1}$ of which 400

\footnotetext{
*Corresponding author. DIW Berlin - German Institute for Economic Research, Mohrenstrasse 58, D-10117 Berlin, Germany. Tel.: +49-30-89789-679, fax: +49-30-89789-200, mail: acullmann@diw.de

${ }^{1}$ Estimation based on data available for $25 \mathrm{EU}$ countries and Norway (EURELECTRIC, 2013).
} 
billion Euros will be invested in distribution grids. ${ }^{2}$ Presently, the design of Europe's electricity distribution and the respective regulatory framework comprises 2,400 DSOs, 260 million connected customers, 240,000 people employed, and 2,700 TWh of annual distributed electricity (EURELECTRIC, 2013). Motivated by the need to design incentives that will foster DSOs' investments in the region's energy networks, in this paper we analyze the investment behavior of DSOs in Germany, which introduced an incentivebased regulatory regime with revenue caps in 2009. Our objective is to gain insights that could be used to improve or revise present-day incentive mechanisms.

Generally speaking, DSOs' strategic behaviors and investment decisions are influenced by market mechanisms, institutional constraints, and firms' own economics. Since the 1990s, however, regulation in the EU has become an important influence due to the changeover from traditional rate-of-return (with cost-plus) regulation to various forms of incentive regulation. ${ }^{3}$ The theoretical literature has noted a close relationship between the investment behavior of regulated companies and the respective regulatory scheme (Guthrie, 2006). Egert (2009), finds that in network industries both rate-of-return and incentivebased regulation can yield (over-) underinvestment depending on the regulatory design. Thus, robust empirical support for explanation of the investment behavior of firms is needed, however existing literature is very limited. ${ }^{4}$

Most of the empirical literature focuses on general cross-country studies of different regulated sectors, and uses data from only the largest European companies. For instance, Cambini and Rondi (2010), who investigate the relationship between investment and regulatory regimes (incentive versus rate-of-return regulation) for a sample of EU energy utilities operating in the electricity and gas transmission and distribution sectors from 1997 to 2007, find a higher investment rate under incentive regulation. Egert (2009) analyzes the effect of the overall regulatory framework on sectoral investments in network industries (energy, water, rail, and telecommunications) using data from different OECD countries, and concludes that the joint implementation of incentive and independent sector regulations have a positive influence on network investments. Alesina et al. (2005) investigate the effects of regulation on investment in the transport (airlines, road freight, and railways), communication (telecommunications and postal) and utilities (electricity and gas) sectors in the OECD, and find that regulation is negatively related to investment. Poudineh and Jamasb (2014), who analyze the determinants of investments for 129 Norwegian electricity distributing companies operating from 2004-2010 5 do not analyze changes in the regulatory scheme.

\footnotetext{
${ }^{2}$ For Germany the volume of investments is expected to reach 27.5 Billion Euro until 2030 (dena, 2012). Investments undertaken by DSOs include building new capacity and replacing existing assets. Investments are also driven by new loads like electric vehicles, expanded rooftop solar, and widespread smart meter deployment.

${ }^{3}$ Across European countries price or revenue cap regulation is extensively used in electricity distribution. Within this framework the price or revenue caps are set based on the general formula $R P I-X$, thus the maximum rate of price (revenue) increase equals the inflation rate of the retail price index $(R P I)$ less the expected efficiency savings $(X)$.

${ }^{4}$ The empirical literature considering the link between regulation and investment incentives mainly focuses on investments in the American telecommunications sector. For example, Greenstein et al. (1995) emphasize that incentive regulation helped to promote the deployment of new technologies in the sector in the late 1980s and early 1990s.

${ }^{5}$ They find that investments are mainly driven by the investment rate in the previous year, the socio-economic costs of energy not supplied, and the useful life of assets.
} 
In this paper we derive a microeconometric investment model based on Hubbard (1998) and Lyon and Mayo (2005) which controls for firm-specific heterogeneity in terms of the differences in the production technology and the size of the electricity distribution companies. ${ }^{6}$ We also control for their ownership structure, since local governments still own shares in most of the distribution companies in our sample (Martimort, 2006). ${ }^{7}$ To estimate the investment model, we apply two different instrumental variable (IV) estimation procedures based on the general method of moments (GMM): the IV GMM framework according to Hansen (1982), and the system GMM following Blundell and Bond (1998) and Arellano and Bover (1995). Our firm-level data from the German Federal Network Regulator (Bundesnetzagentur) includes financial and regulatory information that, to our best knowledge, has not appeared in the literature.

This paper makes three important contributions. First, we analyze the general impact of the transition and the specific institutional and regulatory constraints on DSOs' investment decisions and behaviors by considering a specific country (Germany) where the regulatory scheme changes from rate-of-return to incentive regulation. ${ }^{8}$ Second, the empirical model focuses on the firm-specific factors, e.g., network characteristics, or the geographic area, which significantly influence investment decisions. ${ }^{9}$ Third, the sample of 109 firms includes both large and small distribution companies.

The remainder of this paper is organized as follows. Section 2 reviews the literature and presents our two hypotheses. Section 3 details the data, key variables, and summary statistics. Section 4 explains the empirical model and our estimation strategy. Section 5 discusses the empirical findings. Section 6 shows two model extensions whereas Section 7 concludes.

\section{Literature review and two hypotheses}

This section reviews the theoretical literature on the relationship between the regulatory framework and investment incentives. ${ }^{10}$ We note the need to consider the specific design of the regulatory scheme regarding legal and institutional constraints. We then introduce

\footnotetext{
${ }^{6}$ Broer and Van Leeuwen (1994) study the determinants of investment behavior of Dutch industrial firms. They underscore the importance of using detailed firm level panel data to draw robust conclusions for firms' investment behavior.

${ }^{7}$ Bortolotti and Faccio (2009) point out the importance of ownership for the relationship between regulators and regulated firms incentives to invest and for their financial decisions. Bortolotti et al. (2011) study the effect of ownership and regulatory independence on the interaction between capital structure and regulated prices. Kumbhakar and Hjalmarsson (1998) examine the relative performance of public and private ownership of DSOs in Sweden under yardstick competition during 1970-1990.

${ }^{8}$ All electricity distribution companies are regulated via incentive regulation from 2009 onwards in Germany. Consequently, we have no control group (companies which are not under incentive regulation) and we are only able to observe and explain firms' investment behavior over time (before and after the implementation) and are not able to figure out a causal effect of incentive regulation on investment behavior.

${ }^{9}$ The benchmarking literature on DSOs emphasizes the importance of controlling for both observed and unobserved firm-specific heterogeneity to describe the underlying production process (Farsi and Filippini, 2004; Farsi et al., 2006).

${ }^{10}$ We focus on electricity distribution. Another important stream in the literature considers especially investment incentives in electricity generation. For example, Grimm and Zoettl (2013) explicitly focus on investment decisions in quantities of generating capacity for electricity spot market design.
} 
two hypotheses.

\subsection{Rate-of-return versus incentive regulation and investment incentives}

Traditional thinking considers that rate-of-return regulation, which imposes a ceiling on the rate-of-return on capital, leads to firms' overinvestment. In case that the rate-ofreturn exceeds the cost of capital firms substitute capital for labor to increase profit which leads to a high capital labor ratio and therefore allocative inefficient firms (Averch and Johnson, 1962). Recent literature shows that under certain circumstances, such as the timing of the regulatory cycle, or the level of uncertainty, under-investment can occur (Egert, 2009). Besanko and Spulber (1992) show that under rate-of-return regulation, the regulators' lack of commitment can lead to underinvestment.

Traditional thinking on incentive regulation considers that price caps are superior to rate-of-return regulation when considering cost-reducing investments (Cabral and Riordan, 1989). Clemenz (1991) shows that over time, price cap regulation provides stronger incentives when cost-reducing $R \& D$ investments are viewed as an ongoing process. However, models using real option theory (Nagel and Rammerstorfer, 2008; Roques and Savva, 2006) show that firms cut their investments in cost reductions when encountering a combination of uncertain demand and price caps that are too binding. Rovizzi and Thompson (1995) and Markou and Waddams Price (1999) study whether cost reductions are only achieved at the expense of service quality. ${ }^{11}$

Regulation has different effects depending on the type of investment, e.g., investments in R\&D, service quality, network expansion, etc. (Guthrie, 2006; Dalen, 1998). Incentivebased regulatory regimes introduce new challenges regarding the total level of investment. Some studies suspect that price (revenue) cap regulation prevents firms from investing in network expansion (Poudineh and Jamasb, 2013), while Brunekreeft and Meyer (2011) show that total investment incentives are weakened when additional capital costs from investments lead to corresponding adjustments in the revenue cap only with a time delay (e.g. in the next regulatory period).

In contrast to rate-of-return regulation, the total investment incentives under incentive regulation may be reduced, since the regulated companies are involved more in the risks of the investment in terms of future cash flows and demand changes (Armstrong and Sappington, 2006). Based on modeling tools of real option analysis, Dixit and Pindyck (1994) show that under uncertainty delaying investments may be beneficial, even though a project may recover its capital costs. Dobbs (2004) emphasizes that price cap regulation under uncertainty causes regulated firms to postpone investments.

Guthrie et al. (2006) show the effect of different asset valuation methods to determine the regulatory asset base on firms' investment behaviors. Thus, cost disallowances (costs that are not accepted by the regulator to include in the rate base) may lead firms to cut back or reschedule investments. Similarly, the application of benchmarking methods ${ }^{12}$ to determine the efficiency value and thus the cost savings in the price (revenue) cap

\footnotetext{
${ }^{11}$ Adjusting the regulated price with a measure of quality prevents firms from reducing service quality and thereby increasing profits.

${ }^{12}$ For an overview of benchmarking methods within incentive regulation see e.g. Farsi and Filippini (2004) and Farsi et al. (2006).
} 
can affect the DSOs' strategic investment behaviors. For example, Poudineh and Jamasb (2013), who study DSOs in Norway, show that investment decisions depend on the efficiency level attained in the previous period and the expected efficiency value in the next period.

Our review of the literature reveals the absence of robust support for a link between incentive regulation and firms' total investments: on the one hand, investment incentives in cost reducing investment increases whereas total investment incentives can decrease due to the higher risk carried by the companies compared to rate-of-return regulation (Cabral and Riordan, 1989; Armstrong and Sappington, 2006). It is also possible that specific institutional constraints may reduce investment incentives. This leads to our first hypothesis:

H1: The implementation of incentive regulation has a negative impact on firms' total investments.

\subsection{Timing investment decisions}

Much of the theoretical literature emphasizes the influence of specific institutional and legal requirements on the investment incentives of regulated companies (Guthrie, 2006). Several studies conclude that price (or revenue caps) are based on investments or cost decisions and their timing, and therefore, are not strictly exogenous to the firms. For example, regulated companies tend to invest directly after a regulatory review in order to maximize payoff (Sweeney, 1981), i.e., the firms enjoy excess profits until regulators reduce prices to a level consistent with the new conditions. Biglaiser and Riordan (2000) show that under price caps, investment in cost reduction is more likely to occur in the early years of a regulatory cycle, and that the incentives for replacement investments increase under dynamic price cap regulation as long as newer equipment leads to technical progress. Pint (1992) shows that when regulatory hearings occur at fixed intervals and the timing is known in advance, under price cap regulation, companies plan their capital choices across the regulatory cycle. Assuming that companies maximize the discounted sum of future profits, Pint concludes that higher investment tends to occur in periods when costs are being measured for regulatory purposes. This leads to our second hypothesis:

H2: Firms increase their total investments in the base year.

Figure 1 illustrates Germany's incentive regulation. The German Federal Network Agency (Bundesnetzagentur) calculates price caps based on a cost review and assigns the caps at fixed intervals. The regulatory cost basis of the distribution system operators is determined two years before the start of the regulatory period. Germany defines the cost basis as the last complete financial year at that point in time, and calls the last complete year the base year. The cost situation in the base year is therefore crucial for determining the revenue cap for the following regulatory period. Investments made in the base year are given special consideration. 


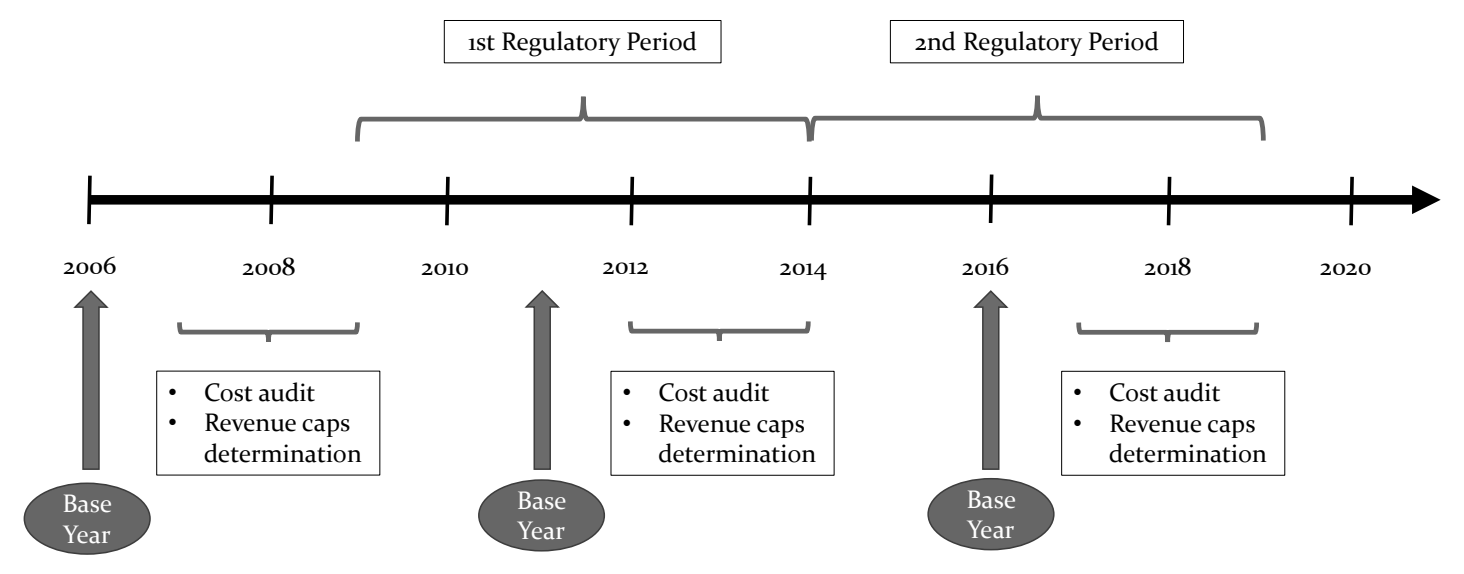

Figure 1: Timeline of incentive regulation for DSOs in Germany.

\section{Data set and key variables}

We use unique information from the German Federal Network Agency (Bundesnetzagentur) on annual financial, technical and regulatory firm-level data for 109 DSOs operating in 2006-2012. ${ }^{13}$ During this timeframe, the regulatory regime switches to incentive regulation with revenue caps. We merge GDP (NUTS 2 level) data to construct our panel dataset. Sections 3.1 through 3.4 below describe the key variables, and Tables 1 to 3 list the summary statistics for the investment data, the firm-specific factors, and the general variables. ${ }^{14}$

\subsection{Investment rate}

The investment rate $I n v_{-} r a t e_{i t}$ of DSO $i$ observed in each year $t$ indicates the amount of total investment relative to current tangible fixed assets as a percentage, where

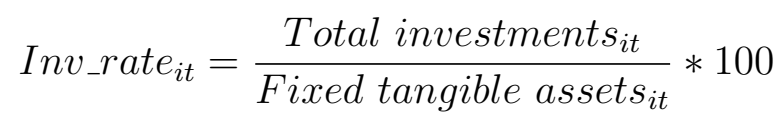

We calculate Total investments $s_{i t}$ based on the balance of acquisitions and disposals by investment groups and the fiscal year as specified by the DSOs. Figure 2 shows the average investment rates $_{i t}$ both at historical acquisition/production cost values and at real current values from 2006 through 2012. Initially, both rates decline, reaching 2.3 percent and 1.9 percent, respectively, in 2008, both increase by almost one percent by 2011, and then both fluctuate at 2 percent and 2.5 percent, respectively, in 2012. For the empirical analysis we only focus on investment rates based on tangible fixed assets

\footnotetext{
${ }^{13}$ The German Federal Network Agency has randomly selected 109 DSOs. For 100 companies we have the full set of variables available which we need to test our model. The companies represent a valid approximation of the whole population of the approximately 800 DSOs in Germany. The data collection and validation are available at http://www.bundesnetzagentur.de (Bundesnetzagentur, 2013).

${ }^{14}$ As the data base is not public, we are not allowed to show the maximum and minimum in the descriptives.
} 
Total investments $s_{i t}$

\begin{tabular}{crrrrr} 
Year & $\mathrm{N}$ & Mean & $\mathrm{p} 25$ & $\mathrm{p} 50$ & $\mathrm{p} 75$ \\
\hline \hline 2006 & 109 & $1.11 \mathrm{E}+07$ & 484642.6 & 1162671 & 5221047 \\
2007 & 109 & $1.07 \mathrm{E}+07$ & 456243.5 & 1009718 & 3520478 \\
2008 & 109 & $1.02 \mathrm{E}+07$ & 405401.8 & 961737.8 & 3009789 \\
2009 & 109 & $1.14 \mathrm{E}+07$ & 408819.6 & 913081.9 & 4482195 \\
2010 & 109 & $1.61 \mathrm{E}+07$ & 624135.9 & 1239230 & 5281863 \\
2011 & 109 & $1.43 \mathrm{E}+07$ & 672707.4 & 1382268 & 5383196 \\
2012 & 109 & $1.13 \mathrm{E}+07$ & 548474.7 & 1179116 & 3567044 \\
$2006-2012$ & 763 & $1.22 \mathrm{E}+07$ & 484642.6 & 1141241 & 5046792
\end{tabular}

\begin{tabular}{crrrrr} 
& & \multicolumn{5}{c}{ Inv_rate $_{i t}$} \\
\cline { 3 - 6 } Year & $\mathrm{N}$ & Mean & $\mathrm{p} 25$ & $\mathrm{p} 50$ & $\mathrm{p} 75$ \\
\hline \hline 2006 & 107 & 2.963 & 1.682 & 2.331 & 3.465 \\
2007 & 108 & 3.634 & 1.624 & 2.165 & 3.001 \\
2008 & 108 & 2.441 & 1.413 & 1.898 & 2.709 \\
2009 & 108 & 2.294 & 1.402 & 2.066 & 2.719 \\
2010 & 108 & 3.425 & 1.785 & 2.481 & 3.431 \\
2011 & 109 & 3.285 & 1.922 & 2.809 & 3.541 \\
2012 & 109 & 2.489 & 1.455 & 2.083 & 2.835 \\
$2006-2012$ & 757 & 2.933 & 1.564 & 2.202 & 3.192 \\
& & & & &
\end{tabular}

Notes: Total investments it $_{\text {are }}$ measured in real current values in Euro. Inv_rate ${ }_{i t}$ indicates the amount of total investment relative to current tangible fixed assets as a percentage.

Table 1: Summary statistics: Total investments and investment rates

at current values of acquisition and manufacturing costs. ${ }^{15}$

\subsection{Regulatory variables}

We define a dummy Incen_Reg that takes the value of one from 2009 and after,

$$
\text { Incen_Reg }{ }_{t}= \begin{cases}1 & \text { if year } t \geq 2009 \\ 0 & \text { if year } t<2009\end{cases}
$$

since all DSOs in Germany are subject to incentive regulation from 2009 onward. Therefore, we have no control group, i.e., firms not subject to incentive regulation, and we are only able to observe and explain firms' investment behaviors before and after the implementation.

We test the impact of implementation together with the firm-specific efficiency value,

\footnotetext{
${ }^{15}$ We do not model the investments based on commercial law calculations, since they are largely characterized by accounting differences. The regression results would not be meaningful in this case because a clean separation between accounting differences and the possible causal relationship of variables is not possible. We omit investment definitions at historical values of tangible fixed assets. We do not consider investments plus the costs of service and maintenance since the latter costs are only reported in terms of commercial law.
} 


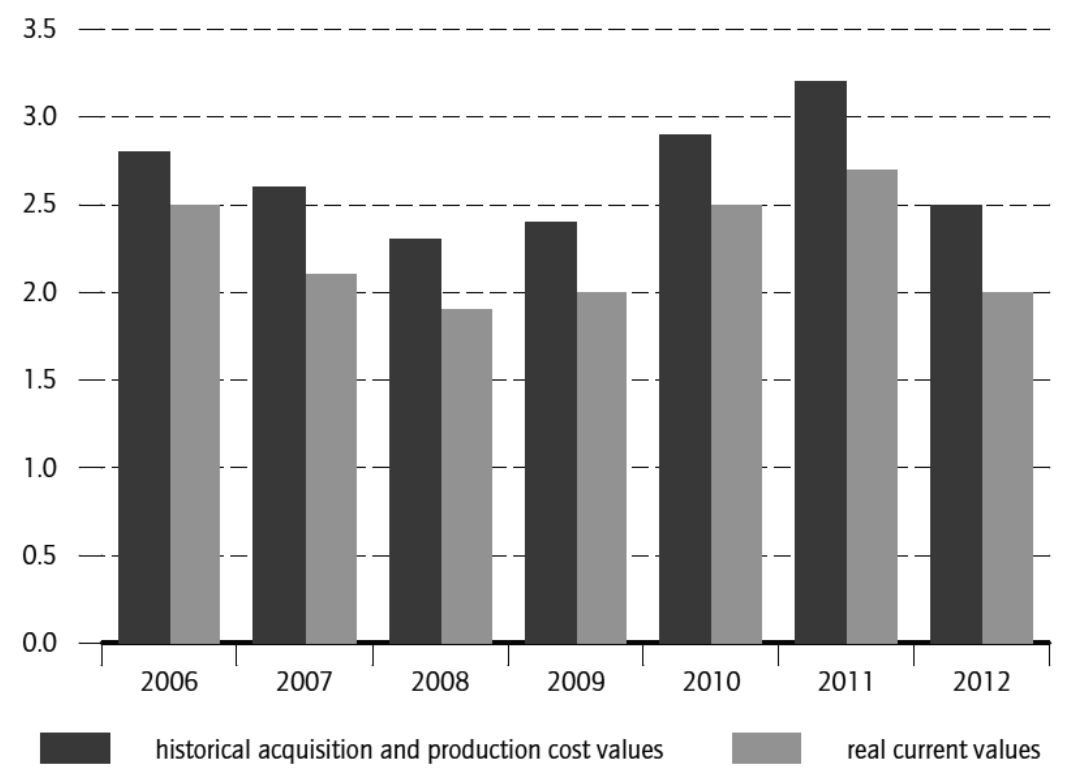

Figure 2: Investment rates 2006-2012 for 109 German DSOs

Eff_Value $e_{i}$, the companies obtained in the first regulatory period starting in 2009. We define $E f f_{-} V_{a l u e}$ as

$$
\text { Eff_Value } f_{i}=1-X_{i}
$$

where $X_{i}$ represents the firm-specific cost reduction obligations determined by the regulator. The efficiency value for the first regulatory period is assigned to the companies in 2009 and determined in the previous year (2008) with cost data from 2006. A higher Ef $f_{-}$Value $_{i}$ means a higher firm-specific efficiency with less cost reduction obligation $X_{i}$. The efficiency score is firm-specific and constant for the whole observation period. We include the efficiency level in the regression, because DSOs with a relatively low efficiency value have an inefficient (too high) investment level and have incentives to decrease the investment level over time. Note that DSOs with a relatively high efficiency level are already characterized by a more efficient investment level and have therefore on average a higher investment rate.

Following Pint (1992) and Biglaiser and Riordan (2000), we disaggregate the implementation of incentive regulation from the effect of the base year to determine if the firms invest more in the base year to increase the rate base. Therefore, we include the year dummy ${ }^{16}$

$$
\text { Base_Year }{ }_{t}= \begin{cases}1 & \text { if year } t=2011 \\ 0 & \text { if year } t \neq 2011\end{cases}
$$

Since the base year effect is indistinguishable from a general price shock in the same year, the dummy years give only limited information on whether individual legal regulations or

\footnotetext{
${ }^{16}$ In our observation period we are only able to test the base year effect for the second regulatory period.
} 
standards are responsible for a different investment behavior. Against this background it is questionable if the expansion of decentralized generation under the Germany's Renewable Energy Law (Energiewirtschaftsgesetz, EEG) could have been the driving force for investment decisions in specific years. In different specifications we control for the base year effect and decentralized generation Decen_Gen $n_{i t}$, which we define as the annual firm-specific rate of change of decentralized generation capacity in high voltage lines. ${ }^{17}$

$$
\triangle \text { Decen_Gen }_{i t}=\frac{\text { Decen_Gen }_{i, t}-\text { Decen_Gen }_{i, t-1}}{\text { Decen_Gen }_{i, t-1}}
$$

\subsection{Firm-specific characteristics and ownership structure}

As mentioned, firms' specific factors related to network characteristics, specificities of the distribution area ${ }^{18}$ and ownership structure affect DSOs' investment decisions. Section $24 \mathrm{ARegV}$ of the Incentive Regulation Law establishes a threshold of fewer than 30,000 customers connected directly or indirectly to a firm's distribution system. The smaller DSOs obtain, a priori, an efficiency score of 87.5 percent in the first regulatory period and 96.14 in the second regulatory period (simplified procedure). Thus, we account for the size of the DSOs defining a dummy variable, Size, that takes the value of one if the distribution network operator in the first regulatory period is small, other- wise zero if the system operator is large. Of the 109 companies in our sample, we characterize 64 as small.

$$
\text { Size }_{i}= \begin{cases}1 & \text { if company takes part in simplified procedure (Sec } 24 \mathrm{AregV}) \\ 0 & \text { if company does not take part in simplified procedure }\end{cases}
$$

To capture firm-specific network differences, we control for the number of connection points $C P_{i t}$ and the service area size $A R_{i t}{ }^{19}$ We define connections points as the points where the consumer "removes" the electricity. The regulator identifies connection points by voltage level. We consider the number of connection points for low $\left(C P_{-} L V_{i t}\right)$ and medium voltage $\left(C P_{-} M V_{i t}\right)$, because DSOs are primarily concerned with these parameters. We define service area as the size of the total distribution area of a network operator in square kilometers, differentiated between low voltage $\left(A R_{-} L V_{i t}\right)$ and medium voltage $\left(A R_{-} M V_{i t}\right)$.

We define ownership structure as public and private based on whether a DSO has purely public shares or private shares. We define mixed ownership based on unclear identification and otherwise. We assume the same ownership status across the timeframe. We define a dummy Public which takes the value of one if the DSO is public and a dummy Mixed which takes the value of one if the DSO has a mixed ownership. Of the 109 firms in our sample 48 are public, 25 are private and 36 are mixed/unclear. ${ }^{20}$

\footnotetext{
${ }^{17}$ Not all of the DSOs in our sample feed in decentralized generation in their high voltage lines. Therefore, including control variable Decen_Gen $i t$ reduces our sample to 58 observations per year.

${ }^{18}$ see e.g. Jamasb and Pollitt (2001, 2003); Cullmann (2012).

${ }^{19}$ Accounting for a firm's connection points and service area size reflects the idea that large urban or large regional DSOs exhibit different investment behaviors than small rural DSOs.

${ }^{20} \mathrm{We}$ are aware that the complex ownership structure of DSOs requires further research based on detailed information about the shares.
} 


\begin{tabular}{|c|c|c|c|c|c|c|}
\hline Year & Variable & Obs. & Mean & $\mathrm{P} 25$ & P50 & P75 \\
\hline \multirow[t]{5}{*}{2006} & $A R_{L V}$ & 101 & 208.27 & 10 & 17 & 64.53 \\
\hline & $C P_{L V}$ & 109 & 95541.88 & 4864 & 12492 & 31657 \\
\hline & $A R_{M V}$ & 100 & 2262.08 & 33.6 & 76.06 & 196.89 \\
\hline & $C P_{M V}$ & 109 & 3035.17 & 43 & 179 & 982 \\
\hline & Eff_Score & 106 & 0.897 & 0.875 & 0.875 & 0.909 \\
\hline \multirow[t]{6}{*}{2012} & $A R_{L V}$ & 109 & 202.88 & 10.1 & 17.55 & 64.64 \\
\hline & $C P_{L V}$ & 109 & 98561.28 & 6617 & 14422 & 36457 \\
\hline & $A R_{M V}$ & 108 & 2226.97 & 44.54 & 77.24 & 235.87 \\
\hline & $C P_{M V}$ & 109 & 3185.23 & 69 & 221 & 1056 \\
\hline & Eff_Score & 106 & 0.897 & 0.875 & 0.875 & 0.909 \\
\hline & $\triangle D e c e n \_G e n$ & 63 & 0.015 & 0 & 0 & 0 \\
\hline \multirow[t]{6}{*}{ Total } & $A R_{L V}$ & 744 & 204.61 & 9.72 & 17.25 & 64.53 \\
\hline & $C P_{L V}$ & 762 & 97559.85 & 5419 & 13847 & 36016 \\
\hline & $A R_{M V}$ & 735 & 2203.37 & 34.7 & 76.08 & 226 \\
\hline & $C P_{M V}$ & 763 & 3166.59 & 60 & 208 & 983 \\
\hline & Eff_Score & 742 & 0.897 & 0.875 & 0.875 & 0.909 \\
\hline & $\triangle D e c e n \_G e n$ & 374 & 0.015 & 0 & 0 & 0 \\
\hline
\end{tabular}

Notes: $A R_{L V}, A R_{M V}$ are measured in square kilometers. $\triangle D e c e n_{-} G e n$ represents the annual firm-specific rate of change in high voltage lines and is not available for the year 2006. Summary statistics for the years 2007-2011 are available upon request.

Table 2: Summary statistics - Firm-specific characteristics

$$
\begin{aligned}
& \text { Public }_{i}= \begin{cases}1 & \text { if company is public } \\
0 & \text { otherwise }\end{cases} \\
& \text { Mixed }_{i}= \begin{cases}1 & \text { if company is mixed } \\
0 & \text { otherwise }\end{cases}
\end{aligned}
$$

\subsection{General variables driving investment}

Following the microeconometric investment literature, we include three general variables to explain the DSOs' investment behaviors:

1. Long-term interest rate, In $R_{t}$ : Based on government bonds with a remaining term to maturity of ten years issued by the German government as a risk-free alternative investment instrument during our timeframe. In $R_{t}$ controls for the cost of capital.

2. Gross domestic product, GDP: Controls for the general economic situation and common effects over time due to business cycles. We use two definitions, on the national level $\left(G D P_{\text {National }}\right)$, and on the regional level $\left(G D P_{\text {Regional }}\right)$, depending on the model specification. ${ }^{21}$

\footnotetext{
${ }^{21}$ We assign each DSO a regional GDP based on the location of the grid areas in administrative districts and urban districts (NUTS 2 level).
} 


\begin{tabular}{lllllll} 
Year & Variable & Obs. & Mean & P25 & P50 & P75 \\
\hline \hline \multirow{2}{*}{2006} & GDP_National & 109 & 103.730 & 103.730 & 103.730 & 103.730 \\
& GDP_Regional & 109 & 103010 & 34489.46 & 60292.61 & 88134.15 \\
& Sales & 107 & $1.75 \mathrm{E}+08$ & $5.20 \mathrm{E}+06$ & $1.13 \mathrm{E}+07$ & $5.68 \mathrm{E}+07$ \\
& InR & 109 & 3.764 & 3.764 & 3.764 & 3.764 \\
2012 & & & & & \\
& GDP_National & 109 & 111.180 & 111.180 & 111.180 & 111.180 \\
& GDP_Regional & 109 & 110576 & 36699.01 & 64760.96 & 91102.91 \\
& Sales & 109 & $1.79 \mathrm{E}+08$ & $6.47 \mathrm{E}+06$ & $1.16 \mathrm{E}+07$ & $5.09 \mathrm{E}+07$ \\
& InR & 109 & 1.495 & 1.495 & 1.495 & 1.495 \\
Total & & & & & & \\
& GDP_National & 763 & 107.094 & 103.730 & 107.250 & 110.200 \\
& GDP_Regional & 763 & 106632 & 35115.96 & 60767.56 & 90367.8 \\
& Sales & 760 & $1.66 \mathrm{E}+08$ & $6.11 \mathrm{E}+06$ & $1.10 \mathrm{E}+07$ & $5.84 \mathrm{E}+07$ \\
& InR & 763 & 3.148 & 2.608 & 3.223 & 3.984
\end{tabular}

Notes: Annual sales are measured in Euro. GDP (National and Regional) is provided by the Statistical Offices of the Federation and the Länder. GDP_National is adjusted by price, seasonal and calendar effects. Summary statistics for the years 2007-2011 are available upon request.

Table 3: Summary statistics - General variables driving investment

3. Sales, diff $f_{-} Y_{i t}$ : Difference of sales from the previous to the current year. The variable accounts for any exogenous shock in demand, e.g. a cold winter. ${ }^{22}$

\section{Empirical implementation}

\subsection{Estimation equation}

We derive our investment equation with the general investment drivers taken from the microeconometric literature on firms' investment behavior (Hubbard, 1998; Lyon and Mayo, 2005; Cambini and Rondi, 2010). We further control for observable firm-specific heterogeneity of firms operating in the electricity distribution sector (Jamasb and Pollitt, 2003). We assume a loglinear relation for the investment model. To account for potential outliers in the data, we median correct all variables (apart from the dummies).

\footnotetext{
${ }^{22}$ The consideration of the demand by sales (or revenues) corresponds to the usual approach in the literature. The empirical challenge for DSOs is that their sales (revenues) are regulated. This variable might reflect changes in demand and/or regulated prices.
} 
Specifically,

$$
\begin{aligned}
& \log \text { Inv_rate }_{i t}=\alpha_{0}+\alpha_{1} \log \text { Inv_rate }_{i, t-1}+\sum_{\tau=1}^{2} \alpha_{2} \text { diff_log } Y_{i, t-\tau} \\
& +\sum_{\tau=1}^{2} \alpha_{3} \log \operatorname{In} R_{i, t-\tau}+\sum_{\tau=1}^{2} \alpha_{4} \log G D P_{t-\tau} \\
& +\beta_{1} \log S i z e_{i}+\sum_{\tau=0}^{1} \beta_{2} \log C P_{-} L V_{i, t-\tau} \\
& +\sum_{\tau=0}^{1} \beta_{3} \log C P_{-} M V_{i, t-\tau}+\sum_{\tau=0}^{1} \beta_{4} \log A R_{-} L V_{i, t-\tau} \\
& +\sum_{\tau=0}^{1} \beta_{5} \log A R_{-} M V_{i, t-\tau}+\beta_{6} \text { Public }_{i}+\beta_{7} \text { Mixed }_{i} \\
& +\gamma_{1} \text { Incen_Reg }_{t}+\gamma_{2} \log E f f_{-} \text {Value }_{i}+\gamma_{3} \text { Base_Year }_{t} \\
& +u_{i}+\epsilon_{i t}
\end{aligned}
$$

where $i$ denotes the $i t h$ firm and $t$ the year. The dependent variable, $\log$ Inv $_{-} r a t e_{i t}$, is the total investment rate for firm $i$ in year $t$. We specify the dependent variable as an autoregressive process, including the lagged dependent variable, $\log$ Inv $_{-}$rate $_{i, t-1}$, as an independent variable. By adding the lagged investment rate and the general and firm-specific control factors, the tested regulatory variables, Incen_Reg, Eff_Value, Base_Year $f_{t}$ effectively capture the deviations from a DSOs investment rate trend.

Instead of using the level of GDP and level interest rate, we include in our main specification the lags starting with $\tau=1, \log I n R_{i, t-1}, \log G D P_{i, t-1}$, to represent the reaction of the current investment decisions on the last period's GDP and interest rate. We test lags up to $\tau=2$ (depending on the specification) of other general variables driving investment and lags up to $\tau=1$ for the firm-specific observed characteristics to determine an optimal lag structure of the right hand side variables. Finally, $u_{i}$ is an unobserved individual effect, which may be correlated with the endogenous regressors, and $\epsilon_{i t}$ is an i.i.d. normally distributed random error, and $\alpha_{0}, \ldots, \alpha_{4}, \beta_{1}, \ldots, \beta_{7}$, and $\gamma_{1}, \ldots, \gamma_{3}$ denote the coefficients to be estimated.

\subsection{Econometric issues and identification}

Since the unobserved firm-specific effects, by construction, correlate with the lagged dependent variables, to obtain consistent estimates, we need to consider the endogenous nature of the lagged investment rate. Therefore, we use different instrumental variable (IV) estimators proposed in the literature (Baum, 2006; Baum et al., 2003). In a first step, we estimate equation 9 using the simple IV GMM estimator according to Hansen (1982), and instrumenting the lagged dependent variable with the $t-2$ lag, $\left(\right.$ Inv_rate $\left._{t-2}\right)$. In this context we allow for heteroskedasticity in $\epsilon_{i t}$; thus the reported standard errors are robust to heteroskedasticity.

In a second step, we use the system GMM estimator following Blundell and Bond (1998) 
and Arellano and Bover (1995). ${ }^{23}$ The widely used system GMM uses lags of levels and differences of the dependent and potentially endogenous or predetermined variables as instruments. More precisely, Blundell and Bond (1998) specify one equation per time period, where the instruments applicable to each equation differ, e.g., in later time periods, additional lagged values of the instruments are available. This involves a new instrument matrix to avoid loss of degrees of freedom. We assume that the unobserved group level effect $u_{i}$ is uncorrelated with changes in the error term $E\left(u_{i} * D \cdot \epsilon_{i t}=0\right)$. Using the one-step cluster robust system GMM estimator, allows us to incorporate time-invariant regressors (versus using two-step difference GMM regressions, (Roodman, 2009)), which is important, because we explicitly model time-invariant factors (such as the size of the firms and the ownership structure).

We assume that the lagged dependent variable $\log$ Inv_rate $_{i, t-1}$ is the only endogenous variable. The general variables driving investment and the firm-specific characteristics as well as the regulatory variables are assumed to be exogenous, thus not correlated with error term. It is also a reasonable assumption for the efficiency value, since we include Eff_Value $f_{i}$ in the model from 2006 onward to control for the efficiency differences between the DSOs. ${ }^{24}$ The efficiency value for the first regulatory period was assigned to the companies by the regulator in 2009 and determined in the previous year (2008) with cost data from 2006. For that reason we argue that the efficiency value is exogenous.

We note that the problem of endogeneity due to temporary and unobserved firm-specific shocks could simultaneously influence a DSO's investments and sales diff $f_{-} \log Y_{i, t-1}$. Therefore, we use several mitigating strategies. First, we use the lagged difference of sales, diff $f_{-} \log Y_{i, t-1}$, to reduce potential endogeneity problems. Second, the flexible framework of system GMM can accommodate multiple endogenous variables. Thus, in another model extension, we account for potential endogeneity of the lagged difference of sales, diff $f_{-} \log Y_{i, t-1}$, by using their lags and lagged difference as internal instruments. Instruments for the endogenous lagged investment rate log Inv_rate $_{i, t-1}$ may be specified as applying to difference equations, the level equations or both (Roodman, 2009). We specify the instruments as applying to the level equations and generate the full set of available moment conditions for the levels equations. ${ }^{25}$ We specify the remaining variables to serve as standard instruments. While it is possible to include all available lags as instruments for endogenous variables, the number of instruments is quadratic in $T$, and it is difficult to manage in empirical applications. Therefore, we specify particular lags (see Section 5.1). ${ }^{26}$

We test the validity of the instruments by using the Sargan Hansen test. ${ }^{27}$ We also con-

\footnotetext{
${ }^{23}$ System GMM uses more instruments than the difference GMM (Arellano and Bond, 1991), so we argue it is appropriate for our sample, because the large number of DSOs increases efficiency of estimation.

${ }^{24}$ If we only include an efficiency score from 2009 and later it would lead to collinearity problems with the dummy Incen_Reg and we could not clearly separate the effects. To determine any causal relationship between the obtained efficiency value and investment decisions, accounting for the dynamic structure with expectations about the efficiency value in the following period (Poudineh and Jamasb, 2013) is beyond the scope of this paper.

${ }^{25}$ It is no longer the case that most are made mathematically redundant by the presence of the full set of moment conditions for the difference equation (Roodman, 2009).

${ }^{26}$ Blundell and Bond (1998) use a small sample to show that this estimator seems to be preferable to other IV and GMM estimators.

${ }^{27}$ The Sargan Hansen test of overidentifying restrictions tests the crucial assumption whether the instruments are exogenous. We report both, the Sargan statistic and the Hansen J statistic for one step
} 
duct a test for autocorrelation of the residuals. The residuals of the differenced equation should possess serial correlation $\mathrm{AR}(1)$, but the differenced residuals should not exhibit significant $\operatorname{AR}(2)$ behavior. Higher-order autocorrelation indicates that some lags of the dependent variable which might be used as instruments are in fact endogenous and therefore are "bad" instruments.

\section{Results}

\subsection{Specification tests}

We begin by testing the robustness of our system GMM estimator. The point estimate of the lagged dependent variable, $\log$ Inv_rate $_{i, t-1}$, has to be smaller than one to ensure convergence. Moreover, unit root tests indicate that the investment rate data generating process is stationary. The results of performing unit-root Fisher-type tests, which are suitable for our unbalanced panels, strictly reject the null hypothesis that the investment rate panel contains unit roots (at the 1 percent significance level).

We test the impact of the difference in sales, $\operatorname{diff} f_{-} Y_{i t}$, and the long-term interest, In $R_{t}$ in various specifications. Both variables show no significant impact in our two models. We therefore deleted them from further regressions.

The specification with $\tau=1$ for the GDP and the firm-specific observed characteristics in levels show an optimal lag structure of the right hand side variables, since higher lags are not significant and lead to implausible point estimates of the remaining variables.

We apply several test statistics to the system GMM estimator. Given that the number of instruments is larger than the potentially endogenous variables, we use the Sargan statistic (and the robust Hansen J statistic) for over-identifying restrictions to test for the joint exogeneity of moment conditions.

The over-identifying restrictions are valid for all estimations. To define the moment conditions, we assume that the system GMM estimator has no serial correlation in the error terms. We apply the Arrellano Bond test for autocorrelation which is applied to the residuals in the first difference equation (Arellano and Bond, 1991). All regressions confirm the first order serial correlation in differences which is confirmed in all regressions. For all of our specifications, the Arrellano-Bond tests show that we can reject the presence of higher-order autocorrelation, i.e. the estimation performs well.

Finally, a problem could be an asymptotic bias of GMM estimators. As Arellano (2003) shows, the bias is of order $T / N$, where $T=6$ is the number of periods and $N=100$ is the number of groups. Related to this problem, an larger instrument collection might overfit potentially endogenous variables, because the number of instruments grows exponentially with the number of periods if we include all available lags in the instrumental matrix (Arellano, 2003; Roodman, 2009). Therefore, we limit the number of lags to $t-2$ for the lagged dependent variable, Inv_rate $t_{-2}$.

The outcomes of the specification tests lead to the following econometric investment model to test our two hypotheses. ${ }^{28}$

robust estimation which is robust to heteroscedasticity and autocorrelation.

${ }^{28}$ It is possible that time-specific factors may influence investment behavior in years other than the base year. As a robustness check, we include a full set of yearly time dummies. Other than the base year, we find no significant influence, and so we omit the other years from the regression (see Section 


$$
\begin{aligned}
\log \text { Inv_rate }_{i t} & =\alpha_{0}+\alpha_{1} \log \text { Inv_rate }_{i, t-1} \\
& +\alpha_{2} \log G D P_{t-1}+\beta_{1} \log \text { Size }_{i}+\beta_{2} \log C P_{-} L V_{i, t} \\
& +\beta_{3} \log C P_{-} M V_{i, t}+\beta_{4} \log A R_{-} L V_{i, t} \\
& +\beta_{5} \log A R_{-} M V_{i, t}+\beta_{6} \text { Public } c_{i}+\beta_{7} M i x e d_{i} \\
& +\gamma_{1} \text { Incen_Reg }_{t}+\gamma_{2} \log E f f_{-} \text {Value }_{i}+\gamma_{3} \text { Base_Year }_{t} \\
& +u_{i}+\epsilon_{i t}
\end{aligned}
$$

\subsection{Control variables}

Tables 4, 5, and 6 show similar regression results for the simple IV-GMM and the system GMM estimators, although there are slight differences in the magnitude of the coefficients and the significance levels of the environmental control factors. In both econometric specifications, the current investment rate significantly depends on the investment rate of the previous period, which indicates a capital stock adjustment. A higher investment rate in the previous period leads to a higher rate of investment in the current period. The lagged national GDP, $\log G D P_{i, t-1}$, accounts for the economic situation. The negative coefficient indicates that the investment rate declines in the current period. ${ }^{29}$

The positive sign of Size shows that the smaller DSOs (less than 30,000 directly or indirectly connected customers) tend to report a higher investment rate. In other words, Germany's incentive regulation law concerning company size significantly influences the DSOs' investment behaviors. The IV-GMM estimator showing that area supplied and number of connections at the low voltage level, $A R_{L V}, C P_{L V}$, have significant impacts (the coefficient of $A R_{L V}$ is positive, whereas it is negative for $\left.C P_{L V}\right)$ on the investment rate ${ }^{30}$ aligns with empirical evidence that rural DSOs have on average a higher investment rate than urban DSOs. Testing the impact of density (defined as the number of connections divided per service area in the low and medium voltage levels), we find that the density variable has a significant negative impact, which also confirms that rural DSOs have on average a higher investment rate. We incorporate the dummies, Public and Mixed, to determine if the differences in investment between public DSOs, or DSOs with a mixed ownership structure, and private DSOs. Since both coefficients are not statistically different from zero for both the IV-GMM and system GMM estimators, there is no empirical evidence that public DSOs behave differently than private DSOs in terms of the magnitude of the investment rates. The finding confirms Cambini and Rondi (2010).

\section{$5.4)$.}

${ }^{29}$ Although the strong negative effect does not seem plausible, further analysis shows that the effect reported here connects to the temporal overlap of two independent events, the global financial crisis in 2008, and the introduction of Germany's incentive regulation in 2009 (see section 5.4 where we estimate an alternative specification with a regional GDP and a year dummy). The regional GDP captures a region's specific economic development and the year dummy variables capture a year-specific effect, such as the global financial crisis in 2008. Since the national GDP varies over time and is not firm-specific, the estimated coefficient can only be interpreted together with the constant. An estimate without a constant leads to a GDP coefficient of -0.171 (p-value 0.035) and nearly identical values for the coefficients (and standard error) of the other base model parameters.

${ }^{30}$ In the system GMM estimation we note the same impact in terms of the sign of the variables, however we note other significance levels. 


\begin{tabular}{|c|c|c|}
\hline Variable & $\begin{array}{r}\text { IV GMM } \\
(1) \\
\end{array}$ & $\begin{array}{r}\text { System GMM } \\
(2)\end{array}$ \\
\hline Inv_Rate $_{t-1}$ & $\begin{array}{r}0.845^{* * *} \\
(0.0712)\end{array}$ & $\begin{array}{r}0.496^{* *} \\
(0.236)\end{array}$ \\
\hline$G D P \_N a t i o n a l_{t-1}$ & $\begin{array}{r}-5.228^{* * *} \\
(1.165)\end{array}$ & $\begin{array}{r}-3.136^{* * *} \\
(1.050)\end{array}$ \\
\hline Size & $\begin{array}{r}0.104^{* *} \\
(0.0483)\end{array}$ & $\begin{array}{l}0.204^{* *} \\
(0.0897)\end{array}$ \\
\hline$A R_{L V}$ & $\begin{array}{r}0.0580^{* *} \\
(0.0271)\end{array}$ & $\begin{array}{r}0.0976^{*} \\
(0.0565)\end{array}$ \\
\hline$C P_{L V}$ & $\begin{array}{r}-0.0549^{* *} \\
(0.0220)\end{array}$ & $\begin{array}{r}-0.0306 \\
(0.0486)\end{array}$ \\
\hline$A R_{M V}$ & $\begin{array}{r}-0.0231 \\
(0.0204)\end{array}$ & $\begin{array}{r}-0.0788^{*} \\
(0.0410)\end{array}$ \\
\hline$C P_{M V}$ & $\begin{array}{r}0.0266 \\
(0.0178)\end{array}$ & $\begin{array}{r}0.0566^{* *} \\
(0.0274)\end{array}$ \\
\hline Public & $\begin{array}{r}-0.00771 \\
(0.0355)\end{array}$ & $\begin{array}{r}-0.0207 \\
(0.0675)\end{array}$ \\
\hline Mixed & $\begin{array}{r}-0.0247 \\
(0.0382)\end{array}$ & $\begin{array}{r}-0.0628 \\
(0.0735)\end{array}$ \\
\hline Constant & $\begin{array}{r}24.37^{* * *} \\
(5.446)\end{array}$ & $\begin{array}{r}14.52^{* * *} \\
(4.905)\end{array}$ \\
\hline $\begin{array}{l}\operatorname{AR}(1) \\
\operatorname{AR}(2)\end{array}$ & & $\begin{array}{l}0.001 \\
0.144\end{array}$ \\
\hline $\begin{array}{l}\text { Sargan Test }\left(\text { Prob }>\chi^{2}\right) \\
\text { Hansen J-Test }\left(\text { Prob }>\chi^{2}\right)\end{array}$ & & $\begin{array}{l}0.116 \\
0.335\end{array}$ \\
\hline $\begin{array}{l}\text { Number of observations } \\
\text { Number of groups } \\
\text { Number of time periods } \\
\text { Number of instruments }\end{array}$ & $\begin{array}{r}483 \\
99 \\
6 \\
11\end{array}$ & $\begin{array}{r}575 \\
100 \\
6 \\
13\end{array}$ \\
\hline
\end{tabular}

Notes: We report IV and system GMM estimates of the base model excluding the regulatory variables, we treat $I n v_{-}$Rate $_{t-1}$ as endogenous. Significance at the 1,5 , and 10 percent levels is represented by $* * *, * *, *$, respectively. Regression results are shown without $\operatorname{dif} f_{-} \log Y_{i, t-1}$ and $I n R_{t-1}$. They were insignificant in all model specifications. We report the p-value of the Sargan test, the Hansen test and the Arrellano-Bond test for autocorrelation.

Table 4: Estimates for base model: Dependent variable is Inv_Rate $_{i, t}$ 


\subsection{Effects of incentive regulation}

We test whether the implementation of the incentive regulation has an impact on the investment behavior of DSOs ${ }^{31}$ by using the dummy variable defined in Section 3.2. The positive and statistically significant coefficient for Incen_Reg $g_{t}$ shown in columns 1 and 2 in Table 5 indicates a significantly higher investment rate after Germany implements incentive regulation in 2009. Our model does not confirm that incentive regulation may introduce the risk of underinvestment in network infrastructure and we reject $\mathrm{H} 1$ (see section 6.3 for a possible explanation). The finding confirms the general cross-country and cross-sectoral analysis by Cambini and Rondi (2010). ${ }^{32}$

The firm-specific efficiency score, $E f f_{-} V a l u e_{i}$, which captures the efficiency differences between individual DSOs, shows that the efficiency value has a positive and significant impact on the investment rate. It follows from the regression results that the DSOs who are relatively more efficient prior to 2009 show on average a higher investment rate. This confirms our idea that companies with a relatively low efficiency value have incentives to decrease their investment levels over time.

\subsection{Effects of the base year}

We test if there is a base year effect assuming that firms increase their investments in the year that serves as the regulators' cost basis for calculating the revenue cap (see Figure 1). The regression includes a base year dummy (Base_Year) defined in Section 3.2. Since the year dummy strongly correlates with Germany's national GDP (national GDP varies by definition only over time and not between individual DSOs), we incorporate the regional GDP, GDP_Regional ${ }_{t-1}$, in the following regressions.

Columns 3 and 4 of Table 5 show that while the impact of the incentive regulation implementation is no longer significant, the coefficient of the base year effect, Base_Year , $_{\text {, }}$ is positive and significantly different from zero. The finding indicates investment decisions made in 2011 drive the observed positive effect of the introduction of incentive regulation on investment (without accounting for the base year). We conclude that the particular design of the incentive regulation with respect to the timing of defining the rate base explains the DSOs' investment behavior of DSOs.

Regarding the base year effect, we note that as a single-year effect it is not distinguishable from a general shock in the base year. Thus, our year dummies provide limited information about whether individual legal regulations or standards are responsible for investment behaviors. As a robustness check, we test if the base year effect is still significant after controlling for decentralized generation, which continually increases in terms of the number of new plants as well as installed capacity in our study period. For example, installed capacity increases by more than ten percent per year from 2009 onward. In contrast, investments and the investment rate in 2012 return to the levels in 2009 and before. The findings suggest that the increase in 2011 is not due to the increase in decentralized generalization. The GMM regressions controlling for the firm-specific annual change rate

\footnotetext{
${ }^{31}$ Due to the dynamic panel data structure and the necessity for instrumenting the lagged investment rate only 2008, before the introduction of incentive regulation, can be considered within the estimation.

${ }^{32}$ Because we are not able to distinguish among the different types of investment, we are not able to determine if the increase in investments is due only to an increase in the cost-reducing investment, as predicted by the literature.
} 


\begin{tabular}{|c|c|c|c|c|}
\hline Variable & $\begin{array}{r}\text { IV GMM } \\
(1) \\
\end{array}$ & $\begin{array}{r}\text { System GMM } \\
(2)\end{array}$ & $\begin{array}{r}\text { IV GMM } \\
(3) \\
\end{array}$ & $\begin{array}{r}\text { System GMM } \\
(4) \\
\end{array}$ \\
\hline \multirow[t]{2}{*}{ Inv_Rate $_{t-2}$} & $0.845^{* * *}$ & $0.571^{* *}$ & $0.828^{* * *}$ & $0.568^{* *}$ \\
\hline & -0.0707 & $(0.244)$ & $(0.0693)$ & $(0.237)$ \\
\hline \multirow[t]{2}{*}{$G D P_{t-1}$} & $-5.105^{* * *}$ & $-3.637^{* * *}$ & 0.0228 & 0.0195 \\
\hline & -1.178 & (1.111) & $(0.0239)$ & $(0.0456)$ \\
\hline \multirow[t]{2}{*}{ Size } & $0.117^{* *}$ & $0.205^{* *}$ & $0.112^{* *}$ & $0.197^{* *}$ \\
\hline & -0.0483 & $(0.0963)$ & $(0.0485)$ & $(0.0940)$ \\
\hline \multirow{2}{*}{$A R_{L V}$} & $0.0590^{* *}$ & 0.0901 & $0.0611^{* *}$ & 0.0874 \\
\hline & -0.0272 & $(0.0590)$ & $(0.0284)$ & $(0.0591)$ \\
\hline \multirow[t]{2}{*}{$C P_{L V}$} & $-0.0541^{* *}$ & -0.0327 & $-0.0551^{* *}$ & -0.0324 \\
\hline & -0.0211 & $(0.0504)$ & $(0.0218)$ & $(0.0501)$ \\
\hline \multirow[t]{2}{*}{$A R_{M V}$} & $-0.0427^{*}$ & $-0.0959^{*}$ & $-0.0473^{* *}$ & $-0.0966^{*}$ \\
\hline & -0.023 & $(0.0497)$ & $(0.0236)$ & $(0.0500)$ \\
\hline \multirow{2}{*}{$C P_{M V}$} & $0.0295^{*}$ & $0.0589 * *$ & 0.0268 & $0.0557^{*}$ \\
\hline & -0.0174 & $(0.0288)$ & $(0.0183)$ & $(0.0288)$ \\
\hline \multirow[t]{2}{*}{ Public } & -0.0122 & -0.0245 & -0.0195 & -0.0313 \\
\hline & -0.0346 & $(0.0704)$ & $(0.0367)$ & $(0.0721)$ \\
\hline \multirow[t]{2}{*}{ Mixed } & -0.0289 & -0.0660 & -0.0320 & -0.0688 \\
\hline & -0.0375 & $(0.0766)$ & $(0.0389)$ & $(0.0765)$ \\
\hline \multirow[t]{2}{*}{ Constant } & $22.86^{* * *}$ & $15.65^{* * *}$ & $-1.075^{* * *}$ & $-1.372^{*}$ \\
\hline & -5.553 & $(5.318)$ & $(0.344)$ & $(0.829)$ \\
\hline \multirow[t]{2}{*}{ Incen_Reg } & $0.104^{*}$ & $0.170^{* * *}$ & 0.0229 & 0.0770 \\
\hline & -0.0615 & $(0.0621)$ & $(0.0761)$ & $(0.0672)$ \\
\hline \multirow[t]{2}{*}{ Eff_Value } & $0.952^{* *}$ & 1.228 & $1.038^{* * *}$ & 1.290 \\
\hline & -0.37 & $(0.910)$ & $(0.371)$ & $(0.923)$ \\
\hline \multirow[t]{2}{*}{ Base_Year } & & & $0.204^{* * *}$ & $0.198^{* * *}$ \\
\hline & & & $(0.0645)$ & $(0.0606)$ \\
\hline $\operatorname{AR}(1)$ & \multicolumn{3}{|c|}{0} & 0 \\
\hline $\operatorname{AR}(2)$ & \multicolumn{3}{|c|}{0.148} & 0.128 \\
\hline Sargan Test $\left(\operatorname{Prob}>\chi^{2}\right)$ & \multicolumn{3}{|c|}{0.213} & 0.187 \\
\hline Hansen J-Test $\left(P r o b>\chi^{2}\right)$ & \multicolumn{3}{|c|}{0.428} & 0.466 \\
\hline Number of observations & 483 & 575 & 483 & 575 \\
\hline Number of groups & 99 & 100 & 99 & 100 \\
\hline Number of time periods & 6 & 6 & 6 & 6 \\
\hline Number of instruments & & & & \\
\hline
\end{tabular}

Notes: We report IV and system GMM estimates of equation 10.

We treat Inv_Rate $_{t-1}$ as endogenous.

Significance at the 1,5 , and 10 percent levels is represented by ${ }^{* * *},{ }^{* *},{ }^{*}$, respectively. We report the p-value of the Sargan test, the Hansen test and the Arrellano-Bond test.

Table 5: Estimates for Hypotheses 1 and 2: Dependent variable is Inv_Rate $_{i, t}$ 
of decentralized generation in high voltage, $\triangle$ Decen_Gen, show that investment rates for 2011 are higher, even with the significant impact of the annual changes in decentralized generation in high voltage (Table 6). This finding confirms the presence of a base-year effect. ${ }^{33}$

\section{Robustness checks}

We check the robustness of our results by extending our model to another investment definition, which uses total investments rather than rates. We also check to see whether the institutional aspect of size influences the DSOs' investment behaviors in the base year. Finally we have a closer look at the German revenue cap determination explaining the rejection of $\mathrm{H} 1$.

\subsection{Another investment definition}

Although we can use total investments of the DSOs while at the same time controlling for size by tangible fixed assets as an independent variable, doing so prevents us from excluding size effects a priori. Therefore, to check for the robustness of our results we use Total investments it $_{\text {it }}$ as the dependent variable and control for the size of the DSOs by tangible fixed assets. To reduce potential endogeneity problems, we use the first lag, Fixed tangible assets $_{i, t-1}$. Table 7 shows that the main conclusions regarding the effect of the incentive regulation and the effect of the base year still hold. Controlling for size by means of the fixed tangible assets, however, shows an insignificant impact of size on the DSOs' investment behaviors. We conclude that Size as an institutional aspect is more important in explaining investment behavior than looking at the total fixed tangible assets.

\subsection{Large DSOs as control group}

To enhance the robustness of our results, we also check to see whether there is a causal interpretation of the base year on the smaller DSOs due to the incentive regulation. We consider the large companies according to the size criteria outlined in the AregV (see Section 3.3) as the control group. In a separate regression, we interact our regulatory variable Base_Year with the Size dummy and test the influence of Size, Base_Year and Base_Year $*$ Size at the same time (see equation 11), where $\alpha_{0}$ represents the average investments in years other than the base year, $\beta_{1}$ the difference in the investment rate between small firms and large firms (other than the base year), $\delta_{1}$ the average investment in the base year, and $\delta_{2}$ the difference and difference estimator, indicating the change in investment rates for small firms relative to large firms in the base year. Table 8 shows the results. Testing Size, Base_Year and Base_Year $*$ Size simultaneously reveals that only the interaction dummy, Base_Year $*$ Size, is not significant. Together with the results in columns $2-4$, we conclude that the smaller companies are not treated differently in the base year. In fact, all of the DSOs in the study period show another investment behavior

\footnotetext{
${ }^{33}$ Assuming that the regulator adds some costs from the second half of the year prior to the base year (2010) to the cost base, a regression with 2010 and 2011 as the base years shows the same results.
} 
Decentralized Generation

\begin{tabular}{|c|c|c|}
\hline \multirow{2}{*}{ Variable } & \\
\hline & $\begin{array}{r}\text { IV GMM } \\
(1)\end{array}$ & $\begin{array}{r}\text { System GMM } \\
(2) \\
\end{array}$ \\
\hline \multirow{2}{*}{ Inv_Rate $e_{t-2}$} & $0.566^{* * *}$ & 0.464 \\
\hline & $(0.171)$ & $(0.311)$ \\
\hline \multirow[t]{2}{*}{$G D P_{-}$Regional $_{t-1}$} & 0.0581 & 0.0454 \\
\hline & $(0.0416)$ & $(0.0427)$ \\
\hline \multirow[t]{2}{*}{ Size } & $0.169^{* *}$ & $0.206^{*}$ \\
\hline & $(0.0842)$ & $(0.124)$ \\
\hline \multirow[t]{2}{*}{$A R_{L V}$} & $0.131^{*}$ & 0.134 \\
\hline & $(0.0775)$ & $(0.101)$ \\
\hline \multirow[t]{2}{*}{$C P_{L V}$} & $-0.0928^{* *}$ & -0.0954 \\
\hline & $(0.0447)$ & $(0.0666)$ \\
\hline \multirow[t]{2}{*}{$A R_{M V}$} & $-0.0915^{* *}$ & -0.0902 \\
\hline & $(0.0431)$ & $(0.0582)$ \\
\hline \multirow[t]{2}{*}{$C P_{M V}$} & 0.0368 & 0.0523 \\
\hline & $(0.0269)$ & $(0.0339)$ \\
\hline \multirow[t]{2}{*}{ Public } & $-0.0821^{*}$ & -0.0861 \\
\hline & $(0.0465)$ & $(0.0847)$ \\
\hline \multirow[t]{2}{*}{ Mixed } & -0.0334 & -0.0304 \\
\hline & $(0.0502)$ & $(0.0832)$ \\
\hline \multirow[t]{2}{*}{ Constant } & $-1.530 * * *$ & $-1.242^{*}$ \\
\hline & $(0.361)$ & $(0.714)$ \\
\hline \multirow[t]{2}{*}{ Incen_Reg } & 0.00390 & 0.00272 \\
\hline & $(0.0675)$ & $(0.0694)$ \\
\hline \multirow{2}{*}{ Eff_Value } & $1.518^{* * *}$ & 1.192 \\
\hline & $(0.387)$ & $(0.797)$ \\
\hline \multirow[t]{2}{*}{ Base_Year } & $0.250 * * *$ & $0.243^{* * *}$ \\
\hline & $(0.0495)$ & $(0.0624)$ \\
\hline \multirow[t]{2}{*}{$\triangle D e c e n \_G e n$} & $0.383^{* * *}$ & $0.394^{*}$ \\
\hline & $(0.0416)$ & $(0.202)$ \\
\hline \multicolumn{2}{|l|}{$\operatorname{AR}(1)$} & 0.007 \\
\hline \multicolumn{2}{|l|}{$\operatorname{AR}(2)$} & 0.023 \\
\hline \multirow{2}{*}{\multicolumn{2}{|c|}{$\begin{array}{l}\text { Sargan Test }\left(\text { Prob }>\chi^{2}\right) \\
\text { Hansen J-Test }\left(\text { Prob }>\chi^{2}\right)\end{array}$}} & 0.191 \\
\hline & & 0.396 \\
\hline \multicolumn{2}{|c|}{ Number of observations } & 336 \\
\hline \multicolumn{2}{|c|}{ Number of groups } & 59 \\
\hline \multicolumn{2}{|c|}{ Number of time periods } & 6 \\
\hline \multicolumn{2}{|c|}{ Number of instruments } & 17 \\
\hline
\end{tabular}

Notes: We treat Inv_Rate $_{t-1}$ as endogenous. Significance at the 1, 5, and 10 percent levels is represented by $* * *, * *, *$, respectively.

We report the p-value of the Sargan test, Hansen test and Arrellano-Bond test. Note that we cannot reject the hypothesis of higher order autocorrelation.

Table 6: Estimates for Decentralized Generation: Dependent variable is Inv_Rate $e_{i, t}$ 
Total Investments

\begin{tabular}{|c|c|c|}
\hline Variable & $\begin{array}{r}\text { IV GMM } \\
(1) \\
\end{array}$ & $\begin{array}{r}\text { System GMM } \\
(2)\end{array}$ \\
\hline \multirow[t]{2}{*}{ Total investments $s_{t-1}$} & $0.798^{* * *}$ & $0.455^{*}$ \\
\hline & -0.0905 & -0.235 \\
\hline \multirow{2}{*}{$G D P_{-} R_{\text {Regional }}{ }_{t-1}$} & $0.0522^{* *}$ & 0.0668 \\
\hline & -0.0264 & -0.0468 \\
\hline \multirow[t]{2}{*}{ Fixed tangible asset $_{t-1}$} & 0.0194 & 0.161 \\
\hline & -0.0464 & -0.135 \\
\hline \multirow{2}{*}{$A R_{L V}$} & $0.151^{* * *}$ & $0.275^{* * *}$ \\
\hline & -0.0457 & -0.0917 \\
\hline \multirow[t]{2}{*}{$C P_{L V}$} & -0.0205 & 0.0446 \\
\hline & -0.0316 & -0.0592 \\
\hline \multirow{2}{*}{$A R_{M V}$} & $-0.0428^{*}$ & $-0.0886^{*}$ \\
\hline & -0.0247 & -0.0456 \\
\hline \multirow{2}{*}{$C P_{M V}$} & $0.0474^{* *}$ & $0.109 * * *$ \\
\hline & -0.0219 & -0.0354 \\
\hline \multirow[t]{2}{*}{ Public } & -0.0513 & -0.0926 \\
\hline & -0.0394 & -0.0756 \\
\hline \multirow[t]{2}{*}{ Mixed } & -0.0614 & -0.116 \\
\hline & -0.0436 & -0.0755 \\
\hline \multirow[t]{2}{*}{ Constant } & $-0.781^{* *}$ & -0.839 \\
\hline & -0.394 & -0.738 \\
\hline \multirow[t]{2}{*}{ Incen_Reg } & 0.0392 & 0.0804 \\
\hline & -0.075 & -0.0637 \\
\hline \multirow{2}{*}{ Eff_Value } & $0.817^{*}$ & 0.872 \\
\hline & -0.437 & -0.835 \\
\hline \multirow[t]{2}{*}{ Base_Year } & $0.211^{* * *}$ & $0.205^{* * *}$ \\
\hline & -0.064 & -0.0577 \\
\hline \multicolumn{2}{|l|}{$\operatorname{AR}(1)$} & 0 \\
\hline \multicolumn{2}{|l|}{$\operatorname{AR}(2)$} & 0.150 \\
\hline \multicolumn{2}{|l|}{ Sargan Test $\left(\right.$ Prob $\left.>\chi^{2}\right)$} & 0.530 \\
\hline \multicolumn{2}{|l|}{ Hansen J-Test $\left(\operatorname{Prob}>\chi^{2}\right)$} & 0.829 \\
\hline Number of observations & 485 & 575 \\
\hline Number of groups & 100 & 100 \\
\hline Number of time periods & 6 & 6 \\
\hline Number of instruments & & 19 \\
\hline \multicolumn{3}{|c|}{$\begin{array}{l}\text { Notes: We report IV and system GMM estimates of equation } 10 \\
\text { with Total investments } s_{t} \text { as the dependent variable } \\
\text { WE treat Total investment } s_{t-1} \text { as endogenous. } \\
\text { Fixed tangible assets } s_{t-1} \text { controls for size. Significance at the } \\
1,5 \text {, and } 10 \text { percent levels is represented by } * * *, * *, * \text {, respectively. }\end{array}$} \\
\hline
\end{tabular}

Table 7: Estimates for model extension: Dependent variable is Total investments $t_{t-1}$ 


$$
\begin{aligned}
\log \text { Inv_rate }_{i t} & =\alpha_{0}+\alpha_{1} \log \text { Inv_rate }_{i, t-1} \\
& +\alpha_{2} \log G D P_{t-1}+\beta_{1} \log \text { Size }_{i}+\beta_{2} \log C P_{-} L V_{i, t} \\
& +\beta_{3} \log C P_{-} M V_{i, t}+\beta_{4} \log A R_{-} L V_{i, t} \\
& +\beta_{5} \log A R_{-} M V_{i, t}+\beta_{6} \text { Public }_{i}+\beta_{7} \text { Mixed }_{i} \\
& +\delta_{1} \text { Base_Year }_{t}+\delta_{2} \text { Base_Year }_{t} * \text { Size }_{+} u_{i}+\epsilon_{i t}
\end{aligned}
$$

\subsection{Germany's revenue-cap formulation}

We surmise that a closer look at the German revenue cap determination can explain the rejection of $\mathrm{H} 1$ where we find empirical evidence that the investment rates do not decrease after 2009. In Germany, revenue caps for DSO $i$ in year $t, R C_{i t}$, are based on the formula,

$$
R C_{i t}=C_{p n c, i t}+\left(C_{t n c, i 0}+\left(1-V_{t}\right) * C_{c, i 0}\right) *\left(\frac{C P I_{t}}{C P I_{0}}-P F_{t}\right) * E F_{i t}
$$

where total costs are differentiated between permanently non-controllable costs $C_{p n c, i t}$ in $t$ and controllable costs. ${ }^{34}$ The controllable costs are further differentiated between temporarily non-controllable costs $C_{t n c, i 0}$ in the beginning of the regulatory period with $t=0$ and controllable costs $C_{c, i 0} \cdot{ }^{35}$ The cost reduction obligation for each DSO is therefore calculated only from the controllable costs. ${ }^{36}$ Thus, a large part of the costs are passed directly to the revenue cap without being subject to any incentive scheme (the nationwide benchmarking).

Other components can determine the revenue caps. ${ }^{37}$ For example, the expansion factor $E F_{t}$ accounts for differences in the service area (e.g., connecting new areas) and ensures that costs for investments resulting from a lasting change in a DSO's supply services during the regulatory period are considered. Moreover, the practical implementation of incentive regulation and the revenue cap determination include elements other than the pure efficiency enhancing and cost reducing incentives which can reduce the risk carried by the DSOs.

\section{Conclusions}

This paper addressed the effects of Germany's implementation of incentive regulation in 2009 on the investment decisions and behaviors of 109 electricity distribution firms

\footnotetext{
${ }^{34}$ Permanently non-controllable costs include for instance the concession fees, taxes, required use of upstream network levels, retrofitting of networks due to electricity from renewable sources and from cogeneration, costs associated with R\&D costs, etc. (see AregV section 11 for a list of all costs.)

${ }^{35} C_{t n c, i 0}$ are defined as the total costs minus the permanently non-controllable costs $C_{p n i, t}$ multiplied by the efficiency value $E f f_{-} V$ alue. To ensure the uniform reduction of controllable costs during the regulatory period a distribution factors $V_{t}$ is defined (ARegV Section 16 para. 1).

${ }^{36}$ Multiplied by the distribution factor $V_{t} * C_{c, 0}$.

${ }^{37} \mathrm{~A}$ general sectoral productivity factor, $P F_{t}$, a consumer price index to capture the general price increase $\frac{C P I_{t}}{C P I_{0}}$, and since 2012 a quality element $Q_{t}$.
} 
Control group (Large DSOs)

Variable

System GMM System GM

System GMM

$(2)$

$(3)$

System GMM

$(1)$

$(4)$

\begin{tabular}{|c|c|c|c|c|}
\hline Inv_Rate $_{t-2}$ & $\begin{array}{r}0.533^{* *} \\
(0.236)\end{array}$ & $\begin{array}{r}0.533^{* *} \\
(0.236)\end{array}$ & $\begin{array}{r}0.511^{* *} \\
(0.235)\end{array}$ & $\begin{array}{c}0.542^{* *} \\
(0.235)\end{array}$ \\
\hline \multirow{2}{*}{$G D P \_$Regional ${ }_{t-1}$} & 0.0157 & 0.0158 & 0.0181 & 0.0291 \\
\hline & $(0.0439)$ & $(0.0439)$ & $(0.0436)$ & $(0.0448)$ \\
\hline \multirow[t]{2}{*}{ Size } & $0.174^{*}$ & $0.188^{* *}$ & 0.111 & \\
\hline & $(0.0978)$ & $(0.0899)$ & $(0.0926)$ & \\
\hline \multirow[t]{2}{*}{$A R_{L V}$} & 0.0891 & 0.0892 & 0.0916 & 0.0788 \\
\hline & $(0.0578)$ & $(0.0577)$ & $(0.0574)$ & $(0.0572)$ \\
\hline \multirow{2}{*}{$C P_{L V}$} & -0.0312 & -0.0311 & -0.0311 & -0.0457 \\
\hline & $(0.0493)$ & $(0.0493)$ & $(0.0490)$ & $(0.0487)$ \\
\hline \multirow[t]{2}{*}{$A R_{M V}$} & $-0.0734^{*}$ & $-0.0735^{*}$ & $-0.0758^{*}$ & -0.0598 \\
\hline & $(0.0419)$ & $(0.0419)$ & $(0.0416)$ & $(0.0402)$ \\
\hline \multirow[t]{2}{*}{$C P_{M V}$} & $0.0530^{*}$ & $0.0530^{*}$ & $0.0533^{*}$ & 0.0300 \\
\hline & $(0.0280)$ & $(0.0280)$ & $(0.0279)$ & $(0.0260)$ \\
\hline \multirow[t]{2}{*}{ Public } & -0.0258 & -0.0259 & -0.0266 & -0.0186 \\
\hline & $(0.0703)$ & $(0.0703)$ & $(0.0699)$ & $(0.0703)$ \\
\hline \multirow[t]{2}{*}{ Mixed } & -0.0645 & -0.0646 & -0.0650 & -0.0563 \\
\hline & $(0.0749)$ & $(0.0749)$ & $(0.0744)$ & $(0.0749)$ \\
\hline \multirow[t]{2}{*}{ Constant } & $-0.174^{* *}$ & $-0.182^{* *}$ & -0.109 & -0.0687 \\
\hline & $(0.0834)$ & $(0.0807)$ & $(0.0780)$ & $(0.0638)$ \\
\hline \multirow[t]{2}{*}{ Base_Year } & $0.196^{* *}$ & $0.218^{* * *}$ & & $0.175^{* *}$ \\
\hline & $(0.0826)$ & $(0.0543)$ & & $(0.0802)$ \\
\hline \multirow[t]{2}{*}{ Base_Year*Size } & 0.0398 & & $0.235^{* * *}$ & 0.0756 \\
\hline & $(0.110)$ & & $(0.0717)$ & $(0.104)$ \\
\hline $\operatorname{AR}(1)$ & 0.000 & 0.001 & 0.002 & 0.001 \\
\hline $\operatorname{AR}(2)$ & 0.139 & 0.190 & 0.266 & 0.196 \\
\hline Sargan Test $\left(\operatorname{Prob}>\chi^{2}\right)$ & 0.132 & 0.135 & 0.149 & 0.142 \\
\hline Hansen J-Test $\left(\right.$ Prob $\left.>\chi^{2}\right)$ & 0.392 & 0.394 & 0.476 & 0.407 \\
\hline Number of observations & 575 & 575 & 575 & 575 \\
\hline Number of groups & 100 & 100 & 100 & 100 \\
\hline Number of time periods & 6 & 6 & & \\
\hline Number of instruments & 15 & 14 & 14 & 14 \\
\hline
\end{tabular}

We report system GMM estimates including the interaction term Base_Year*Size.

Column 2-4 show the separate regressions with the single variables.

We treat Inv Rate $_{t-1}$ as endogenous. Significance at the 1,5 , and 10 percent levels is represented by $* * *, * *, *$, respectively.

Table 8: Estimates with interaction dummy Base_Year*Size: Dependent variable is Inv_Rate ${ }_{i, t}$ 
operating in 2006-2012. Two hypotheses were introduced: implementation of incentive regulation has a negative impact on total investment, and firms increase their investments in the base year. A model was constructed using unique firm-level data and tested with the German data. Robust empirical evidence found that the implementation of incentive regulation had a significantly positive effect on DSOs' total investment rates. The results indicated a strong base year effect, i.e., firms behaved strategically and invested heavily in the base year in order to increase the rate base for the following regulatory periods. The effect was still significant after controlling for the increase in decentralized generation capacities. The stable empirical results found in different model extensions could be explained by the reality that the revenue caps reduced some of the risks carried by the companies under incentive regulation. In summary, Germany's investment incentives continue to be affected by incentive regulation. This insight has particular relevance for Germany's energy transition (Energiewende), and Europe's desire to achieve carbon-free generation.

\section{Acknowledgements}

This paper is produced as part of the project Municipal infrastructure companies against the background of energy policy and demographic change (KOMIED) funded by the Leibniz Commission (SAW-2013-DIW-5). The data collection and preparation and first econometric estimations have been conducted during the project "Study on the investment behavior of electricity and gas network operators as part of the evaluation report in accordance with $\S 33$ para. 1 ARegV". The paper has been presented at the EARIE Annual Conference in Munich, the Annual Conference Verein für Socialpolitik (VfS), and the CEPE Lunch Seminar at ETH Zurich. We further gratefully acknowledge Pio Baake, Tomaso Duso and Christian von Hirschhausen for the valuable comments and suggestions. We further thank Ann Steward for providing language help and proof reading the article. The usual disclaimer applies. 


\section{References}

\section{Bibliography}

Alesina, A., Nicoletti, G., Ardagna, S., Schiantarelli, F., 2005. Regulation and invesment. Journal of the European Economic Association 3 (4), 791-825.

Arellano, M., 2003. Modeling optimal instrumental variables for dynamic panel data models. CEMFI Working Paper 0310.

Arellano, M., Bond, S., 1991. Some tests of specification for panel data: Monte Carlo evidence and an application to employment equations. The Review of Economic Studies 58 (2), 277-297.

Arellano, M., Bover, O., 1995. Another look at the instrumental variable estimation of error-components. Journal of Econometrics 68, 29-52.

Armstrong, M., Sappington, D., 2006. Regulation, competition and liberalization. Journal of Economic Literature XLIV (325-366).

Averch, H., Johnson, L., 1962. Behavior of the firm under regulatory constraint. American Economic Review 52, 1053-1069.

Baum, C. F., 2006. An Introduction to Modern Econometrics Using Stata. College Station TX.

Baum, C. F., Schaffer, M. E., Stillmann, S., 2003. Instrumental variables and GMM: estimating and testing. Stata Journal 3, 1-31.

Besanko, D., Spulber, D., 1992. Sequential equilibrium invesment by regulated firms. Rand Journal of Economics 23 (2), 152-170.

Biglaiser, G., Riordan, M., 2000. Dynamics of price regulation. RAND Journal of Economics 31 (4), 744-767.

Blundell, R., Bond, S., 1998. Initial conditions and moment restrictions in dynamic panel data models. Journal of Econometrics 87 (1), 115-143.

Bortolotti, B., Cambini, C., Rondi, L., Spiegel, Y., 2011. Capital structure and regulation: Do ownership and regulatory independence matter? Journal of Economics \& Management Strategy 20 (2), 517-564.

Bortolotti, B., Faccio, M., 2009. Government control of privatized firms. The Review of Financial Studies 22 (8), 2907-2939.

Broer, D. P., Van Leeuwen, G., 1994. Invesment behavior of Dutch industrial firms. European Economic Review 38, 1555-1580.

Brunekreeft, G., Meyer, R., 2011. Netzinvestitionen im strommarkt: Anreiz- oder hemmniswirkungen der deutschen anreizregulierung? Energiewirtschaftliche Tagesfragen $61(1-2)$. 
Bundesnetzagentur, 2013. Erlaeuterungen zur einleitung der konsultation der datenerhebung fuer den evaluierungsbericht para 33 abs 1 aregv.

Cabral, L., Riordan, M., 1989. Incentives for cost reduction under price cap regulation. Journal of Regulatory Economics 1, 93-102.

Cambini, C., Rondi, L., 2010. Incentive regulation and investment: Evidence from European energy utilities. Journal of Regulatory Economics 38 (1), 1-26.

Clemenz, G., 1991. Optimal price cap regulation. The Journal of Industrial Economics 39 (4), 391-408.

Cullmann, A., 2012. Benchmarking and firm heterogeneity: A latent class analysis for German elecritiy distribution companies. Empirical Economics 42, 147-169.

Dalen, D. M., 1998. Yardstick competition and investment incentives. Journal of Economics \& Management Strategy 7 (1), 105-126.

dena, 2012. Expansion and innovation of the german power distribution networks in 2030 (original in german: dena verteilnetzstudie: Ausbau - und und innovationsbedarf der stromverteilnetze in deutschland). Tech. rep., Deutsche Energieagentur - dena.

Dixit, A. K., Pindyck, R. S., 1994. Investment under Uncertainty. Princeton University Press.

Dobbs, M., 2004. Intertemporal price cap regulation under uncertainty. The Economic Journal 114, 421-440.

Egert, B., 2009. Infrastructure investment in network industries: The role of incentive regulation and regulatory independence. William Davidson Institute Working Paper 956.

EURELECTRIC, 2013. Power distribution in Europe: Facts and figures. EURELECTRIC Paper Series.

Farsi, M., Filippini, M., 2004. Regulation and measuring cost efficiency with panel data models application to electricity distribution utilities. Review of Industrial Organization 25 (1), 1-19.

Farsi, M., Filippini, M., Greene, W. H., 2006. Application of panel data models in benchmarking analysis of the electricity distribution sector. Annals of Public and Cooperative Economics 77 (3), 271-290.

Greenstein, S., McMaster, S., Spiller, P. T., 1995. The effect of incentive regulation on infrastructure modernization: Local exchange companies' deployment of digital technology. Journal of Economics \& Management Strategy 4, 187-236.

Grimm, V., Zoettl, G., 2013. Investment incentives and electricity spot market competition. Journal of Economics \& Management Strategy 22 (4), 832-8511. 
Guthrie, G., 2006. Regulating infrastructure: The impact on risk and investment. Journal of Economic Literature 44 (4), 925-972.

Guthrie, G., Small, J., Wright, J., 2006. Pricing access: Forward-looking versus backward-looking cost rules. European Economic Review 50, 1767-1789.

Hansen, L. P., 1982. Large sample properties of generalized method of moments estimators. Econometrica 50, 1029-1054.

Hubbard, G. R., 1998. Capital market imperfections and investment. Journal of Economic Literature 36, 193-225.

Jamasb, T., Pollitt, M. G., 2001. Benchmarking and regulation: International electricity experience. Utilities Policy 9 (3), 107-130.

Jamasb, T., Pollitt, M. G., 2003. International benchmarking and yardstick regulation: An application to European electricity distribution utilities. Energy Policy 31 (15), $1609-1622$.

Kumbhakar, S. C., Hjalmarsson, L., 1998. Relative performance of public and private ownership under yardstick competition:electricity retail distribution. European Economic Review 42, 97-122.

Lyon, T., Mayo, J., 2005. Regulatory opportunism and investment behavior: Evidence from the U.S. electric utility industry. Rand Journal of Economics 36 (3), 628-644.

Markou, E., Waddams Price, C., 1999. UK utilites: Past reform and current proposals. Annals of Public and Cooperative Economics 70, 371-416.

Martimort, D., 2006. An agency perspective on the costs and benefits of privatization. Journal of Regulatory Economics 30 (1), 5-44.

Nagel, T., Rammerstorfer, M., 2008. Investment decisions under market concentration and price regulation. Working Paper.

Pint, E., 1992. Price cap versus rate of return regulation in a stochastic cost model. RAND Journal of Economics 23, 564-578.

Poudineh, R., Jamasb, T., 2013. Investment and efficiency under incentive regulation: The case of the Norwegian electricity distribution networks. Cambridge Working Papers in Economics 1306.

Poudineh, R., Jamasb, T., 2014. Determinants of invesment under incentive regulation: The case of the Norwegian electricity distribution networks. Energy Economics in press.

Roodman, D., 2009. A note on the theme of too many instruments. Oxford Bulletin of Economics and Statistics 71, 135-158.

Roques, F., Savva, N., 2006. Price cap regulation and investment incentives under demand uncertainty. Cambridge working papers in economics, CWPE 0636, Cambridge.Http://www.cambridgeeprg.com/wpcontent/uploads/2008/11/eprg0616.pdf. 
Rovizzi, L., Thompson, D., 1995. The Regulatory Challenge. Oxford University Press, Ch. The regulation of Product Quality in the Public Utilities.

Sweeney, G., 1981. Adoption of cost-saving innovations by a regulated firm. American Economic Review 71 (3), 437-447. 